\title{
Valuation of the Loss of State Owned Enterprise as the State Losses Based on the Object of Economic Criminal Accountability Perspective
}

\author{
Titik Prasetyowati Verdi ${ }^{1}$, Jamal Wiwoho ${ }^{2}$ I Gusti Ayu Ketut Rachmi Handayani ${ }^{3}$ \\ ${ }^{1.2 .3}$ Universitas Sebelas Maret \\ Surakarta, Indonesia \\ titikprasetyowati@student.uns.ac.id
}

\begin{abstract}
This study aim to the argument for the absorption of SOE losses as the state losses based on the perspective of economic criminal accountability and the form of absorption of SOE losses as the state losses. A state-owned enterprise (SOE) refers to a business enterprise that is owned and controlled by the government, whether wholly or partially. It is a public company where the government is also the owner of the capital from separated state assets. In the practice, SOE business activities tend to be a tool of corruption due to the political intervention toward the SOE. This means that SOEs can lose money due to assignments and government intervention. Ironically, SOE losses that have not been included as the state losses have become a loophole for corruption. This doctrinal study applied primary and secondary legal materials with deductive analysis. The results of the study show that the argument for the valuation of SOE losses as the state losses is due to: a. there is a policy of SOE that is detrimental to the state; b. SOE assets including the state assets, c. The state intervention on SOE business activities.
\end{abstract}

Keywords- State Owned Enterprise, State Loss, Corruption.

\section{INTRODUCTION}

One of the tasks of the state is to balance the role of the private sector, ensuring the needs of the community through public services. The application is to establish a State-Owned Enterprise (SOE) based on Article 33 of the 1945 Constitution. Public service is the fulfillment of community needs by the state administrators.[1] The state is required to be able to meet the needs of the community which are not only individual needs but also health, education, and needs that support the community productivity such as transportation, electricity, fuel, fertilizer, and farmers' plant seeds. Ironically, SOE public services often suffer losses and are also suspected of being a tool for corruption. Thus, it is necessary to initiate the expansion of SOE losses as the objects of criminal accountability.[2]

This idea breaks Law no. 19 of 2003 concerning SOE (SOE Law) and Law no. 40 of 2007 concerning Limited
Liability Companies (UUPT), which shields the SOE losses that it cannot be classified as accountability for criminal acts of corruption. SOE losses are considered reasonable as a consequence of the company.[3]

In fact, there is a state capital through the state budget fully (SOE Perum) or in part (SOE Persero) inside the SOE. The causality of SOEs with corruption is strengthened by the statement of the Minister of SOEs who found 53 cases of SOE corruption that harmed the state. Grammatically, an economic crime is an act in the economic field that can be held criminally accountable. SOEs as state corporations that carry out economic actions, the losses can be included as accountability for economic crimes.[4]

The qualifications of corruption, such as bribery, extortion and nepotism are anatomical with the following characteristics: (i) involving more than one person; (ii) involving confidentiality; (iii) involving an element of liability and reciprocal benefits which are not always monetary; (iv) hidden acts behind the legal justifications, the perpetrator has a strong influence on both economic and political status; (v) containing elements of deception; (vi) containing elements of betrayal of trust and violates norms; and (vii) duties and responsibilities in the society. Thus, there must be a valuation of SOE losses into the state losses as the object of accountability charged to perpetrators of corruption as a form of economic crime.[5]

The valuation of SOE losses into the state losses is strengthened by: (i) SOE capital related to the state capital; and (ii) SOE activities are regulated and directed by the state and this is a loss to the state in terms of causality. The policy of SOE directors can be an act that fulfills a corruption offense, if it can harm state the finances. Article 2 paragraph (1) of the Anti-Corruption Law includes the phrase "harming the finances/economics of the state." State finances according to the AntiCorruption Law are state assets in any form, whether separated or not, including all parts of the state assets, rights and obligations.[6]

The causality is that the state losses caused by SOE losses are a form of economic crime whose regulations are specifically regulated. As long as there is an actual loss to the SOE, it is considered to be detrimental to the finances of the state and by this matter, the directors are held accountable and charged with committing a criminal act of corruption considering that SOE is an economic 
actor and market player whose function is to provide the public welfare.[7] Cases can ensnare directors who are accused of committing a criminal act of corruption with the argument that the SOE they lead caused the state financial losses since the capital obtained by companies such as SOE (Persero) was $51 \%$ from the state. Although there is resistance that SOE capital is a separated state asset so that the loss is subject UU PT. Thus, this article seeks to provide answers regarding: (i) why is it necessary to evaluate SOE losses as the state losses based on the perspective of accountability for economic crimes; and (ii) what is the form of valuation of SOE losses as the state losses based on the perspective of accountability for economic crimes.[8]

\section{FINDINGS AND DISCUSSION}

The objectives of SOE in Article 2 paragraph (1) of the SOE Law are: (i) contributing to the development of the national economy in general and the state revenues in particular; (ii) the pursuit of profit; (iii) providing public benefits in the form of providing high quality and adequate goods and/or services to fulfill the needs of many people; (iv) pioneering business activities that have not been implemented by the private sector and cooperatives; and (v) actively participate in providing guidance and assistance to entrepreneurs from economically weak groups, cooperatives, and the community. The activities of SOEs have not been accompanied by a clear classification of objectives, so that their activities are inconsistent, prone to intervention and cause losses. Data for 2018 shows that 24 SOEs have lost or $20 \%$ of the total 118 active SOEs.[9]

Although the number is less than the data reported in 2013 , with 30 SOEs, the losses are quite large with a total of IDR 32.6 trillion. These cases occur because many directors play a dual role in running SOEs, mixing business affairs and public services. The management of SOE must be carried out accurately and carefully since it manages certain production branches that have an impact on the wider community. The controversy can be seen in the case of rice imports where a farmer group refused an additional 1 million tons of rice import permit for the State Logistics Agency (Bulog). The additional import of rice is detrimental to the rice production of farmers who are enjoying good harvested dry grain prices with a value of Rp. 4,500 to Rp. $5,000 / \mathrm{kg}$.[10]

On the other hand, for the government, additional rice imports are a way to mitigate rice prices which continue to rise due to the limited supply. If the wrong policy concerns the livelihood of the people, such as importing rice, it has the potential to cause misery for the people. Data must be accurate and free of interest, too much power, energy and resources are wasted debating policies based on inaccurate data. The wealth of SOE is regulated in Article 2 letter $g$ of the SOE Law: "State assets/regional assets managed by themselves or by other parties in the form of money, securities, goods receivables, and other rights that can be valued in money, including assets separated from the state companies /regional company.’[11]
Thus, SOE losses are the state losses considering that SOE assets are classified as the state assets from their capital participation. Referring to the form of SOE Persero, which is vaguely subject to UU PT, in fact criminal liability can be drawn since all actions of the company, good and bad, are borne by the company. The management of the company is only an organ that is not responsible for its actions, but it is the responsibility of the person it represents, namely the limited liability company concerned.[12]

This is used to save the directors of SOE Persero from the criminal responsibility and to justify SOE to comply with UU PT, even though the implementation practice is far from the nature of PT. In the practice, the business activities of SOE are not as simple as conventional companies, thick with intervention, tug-of-war of interests that result in SOE losses. In this position, SOE can be positioned as a corporation that becomes a tool of corruption if it is proven that SOE losses cause the state losses. Marshall B. Clinard and Peter C. Yaegar stated: "A Corporate crime is any act committed by sorporations that is punished by the state, regardiess of whether is it punished under administrative, civil, or criminal law.[13]

The theoretical perspective explains the corporation as a subject of criminal law and corporate criminal responsibility. First, identification theory, the actions of corporate management are identified as corporate actions based on the strict liability doctrine or direct responsibility which establishes criminal responsibility or accountability on the perpetrators without proving the guilt of the perpetrators. The identification theory is different from the strict liability where the actions of the management which are the directing mind of the corporation are identified as corporate actions so that the actions taken by the management are imposed on the corporation.[14]

The principle of responsibility based on the presence of an element of error is a reaction to absolute responsibility, no fault liability or absolute/strict that has prevailed in the past, with the formula "a man acts at this peril" or 'any act committed by someone, if it harms another person, causing him to be blamed for violating the law.' Second, the imputation theory is based on the principle of vicarious liability, imputed liability or responsibility transferred to another party by a physical actor due to the relationship between the responsible party and the physical perpetrator. In this case, the writer is in line with the imputation theory, that the relationship proves the relationship between the physical perpetrator and the responsible party. This happens to SOE directors who commit corruption and their causality is proven by other parties related to corruption.[15]

The relationship of the management as a physical actor with the corporation is the main thing, the management must act in the part of work for the benefit of the corporation. There are 3 elements so that the corporation can be held accountable for the actions of the management: (i) the management of the corporation commits a crime; (ii) the crime was committed within the scope of the authority; (iii) for the purpose of corporate 
benefit. Comparison with the Anglo-Saxon state corporate criminal liability theory, strengthens the expansion of SOE losses as the objects of criminal liability including direct corporate criminal liability. In its application, the actions of the management are identified as corporate actions called alter egos. Thus, from a corporate point of view, it opens up space for the expansion of SOE losses as the objects of criminal responsibility.[16]

David Lazer describes the relationship of the state to public companies. First, the state accommodates the best competitors as the standard image of state production. Second, the state creates conditions that allow small competitors to have no power. The state must benefit SOEs through its policies. In this case, intervention through policies that disrupt the performance of SOEs is not justified.[17] However, in the practice, the state is still diligent in conducting various interventions toward SOEs through its policies, up to the level of the government's two-sided actions (materialele daad). Indeed, the government in materiel daad is subject to the rules of civil law, but it is distorted by unhealthy policy interventions, especially for the development and growth of SOEs.[18]

The SOE Law does not explain SOE losses. SOE Persero, for example, is a state company in the form of a PT (Incorporated Company) and the capital is divided into shares, wholly or partially, at least $51 \%$ of the shares are owned by the state from the separated state assets. Participating capital is sourced from APBN, reserve capitalization, and others. Equity participation from the APBN includes the state assets from fresh funds, state goods, state receivables from SOE (Persero), state shares in SOE, and other state assets. Article 11 of the SOE Law emphasizes that in terms of managing SOE Persero, the provisions of the Law on PT. The implication is that the provisions that apply to PT are attached to SOE Persero, such as the separation of wealth between the founders or management.[19]

However, the capital participation from the APBN (State Revenue and Expenditure Budget) is actually the legitimacy of the people to the state through SOE to be managed into output in the form of public services and other things that support the welfare of the people. Thus, if there is a loss in the management of SOE Persero (Incorporated Company), even though it is subject to the Limited Liability Company Law, it cannot be separated from the state losses since the SOE's capital is separated from the state assets even though it places the state as a shareholder. In the practice, the state still determines the policy direction and business activities of SOEs.[20]

The proof is that the Ministry of SOEs and the President can give assignments through Presidential Regulations and other legal products. As a result, SOEs do not only run capital that is separated from the state, but also as a tool of the state in its policies. Thus, SOE losses are no longer the company's losses, but are related to the state losses. This is in 2 points: (i) SOE capital comes from separated state assets, but the state does not only act as a shareholder as stipulated in the Limited Liability Company Law, but in the practice the state largely determines the direction and policies and/or business activities of SOEs; and (ii) The involvement of the state in determining the direction of policies and/or business activities of SOEs makes SOE directors cannot be equated with directors or directors of companies in general as stipulated in UU PT. Thus, the responsibilities of SOE directors are significantly different from the responsibilities of company directors in general. In this case, the phrase that must be expanded regarding losses in the SOE Law is to add to the provision that SOE losses are interpreted as the state losses when the state determines the direction of SOE policies and business activities.[21]

The elements of state losses are regulated in Article 1 number 22 of the State Treasury Law: "Lack of money, securities, goods that are real and definite in amount as a result of legal actions either intentionally or negligently." This understanding is identical to the provisions of the state losses in Law no. 15 of 2006 concerning BPK. However, the definition of state losses in the State Treasury Law, is narrowed down to the phrase "a real and definite amount, as a result of unlawful acts, either intentionally or negligently." Thus, the State Treasury Law in determining the state losses considers the provisions of material offenses, namely the state financial losses must be real and definite in amount proportional to the definition of the state finances.[22]

The elements of state losses are: (i) reduced state finances in the form of valuable money, state property from the amount and/or value that should be; (ii) the lack of state finances must be real and definite in amount, not only an indication or potential loss; and (iii) the loss is the result of an unlawful act, whether intentional/negligent, the element of being against the law must be proven. Referring to this understanding, it is difficult for SOE losses to be declared as the state losses, related to the provisions of Article 1 number 22. The implication is that SOE losses must be proven to be caused by the intentional legal actions or negligence of SOE directors. The Board of Directors in carrying out actions or policies must be based on good faith and in accordance with the AD/ART of SOEs. If the SOE's directors are proven not to have acted in good faith, criminal responsibility will be directed to them.[23]

However, regarding the loss of SOEs, it is necessary to investigate whether it is true that the personal actions of the directors were not in good faith and did not comply with the AD/ART, or whether there was state intervention dictating the policy direction and activities of the SOE's business activities. SOE as a company is the doer of business, therefore, the profit or loss that occurs is normal. However, if the state intervenes in the direction of its policies and business activities and actually causes losses, it must be classified as the state losses.[24]

The basis are: (i) SOEs are not subject to the Law on Limited Liability Companies, with the state intervention in the direction of policies and business activities of SOEs through policies or materielle daad; and (ii) the state is not responsible if SOEs are proven to have suffered losses due to the state intervention. If the state and SOEs do not heed the principles as applicable to State-Owned 
Enterprises (SOE) Persero. Thus, SOE losses can be classified as the state losses so that they meet the elements as objects of criminal responsibility. The expanded phrase related to SOE losses in the State Treasury Law is the provision that if SOE losses are proven to be caused by the state intervention in dictating the direction of policies and activities of SOE business activities, then it becomes a loss to the state.[25]

The practice of SOEs has so far been sparsely subject to the provisions of UU PT which is a savior of SOE losses that cannot be the object of criminal responsibility since it is not a state loss. The provisions of the Limited Liability Company Law do not provide a bright spot for the loss of SOE.[26] Article 11 of the SOE Law emphasizes that in terms of managing SOE, apply the provisions and principles of UU PT. This means that the management of SOE Persero is equated with PT, such as the separation of company assets from owners and management. The assets of State-Owned Enterprises (BUMN) are divided into state capital participation in the form of shares and funding participation from the Public Service Obligation implementation budget which is not included in the assets of the Company.[27]

Wealth that is separated from the APBN then becomes the capital for the establishment of SOE Persero, consisting of shares that will become the wealth of SOE, no longer the state assets due to differences in the position of the state in SOE Persero. When the state enters as part of a state-owned company, its position is equal to other shareholders and is no longer a public legal entity that holds the power to administer the state, but as a private legal entity that is subject to the provisions of the company.[28]

In the practice, this does not happen since the government through policies in the form of assignments or government actions that are not balanced (since the substance of the agreement or contract is dictated by the government) still holds the power to administer the state and is applied to SOEs. In fact, the government stands on two legs and acts subject to UU PT by placing SOE as a private legal institution, but the government still intervenes in the policies and business activities of SOE. The government hinders the explanation of Article 4 paragraph (1) of the SOE Law, where the purpose of separating state assets is to separate the state assets from the APBN as the state capital participation, which further management is no longer based on the government regulations. [29]

However, the government has for some time carried out assignments that cannot be separated from the government's function of regulating SOEs. This is exacerbated by the unexplained budget related to PSO even though it is stated that it is still subject to the provisions of the State Finance Law since the budget is purely from the APBN whose management follows the accountability of the state finances.[30] This adds to the confusion in the practice since there is no firm role of the state in SOE and the capital is separated since it is still subject to the State Finance Law. In the implementation of the PSO, the State-Owned Enterprises are dictated to by the state since it is the state that carries out the public service function. The phrase that expands SOE losses in the Limited Liability Company Law is to state that SOE losses can be classified as the state losses if the loss is an investment fund used by the board of directors unlawfully or by negligence and the funds come from the state budget for public service obligations.[31]

\section{CONCLUSION}

The arguments for the absorption of SOE losses as the state losses in the perspective of accountability for economic crimes are: (i) There are SOE policies that are detrimental to the state; (ii) SOE assets include the state assets and are responsible for the state losses; (iii) there is state intervention in the business activities of SOEs. The form of absorption of SOE losses as the state losses based on the perspective of accountability for economic crimes is applied by adding the following provisions: (i) SOE losses are interpreted as the state losses if the state determines the direction of SOE policies and business activities in Law no. 19 of 2003; (ii) if the loss of SOE is caused by the state intervention, then it becomes the loss of the state in Law no. 1 of 2004; (iii) defines the definition of SOE loss as the state loss if the loss is in the form of participation funds used by the board of directors against the law or negligence and comes from the APBN for public service obligations in Law no. 40 of 2007; (iv) adding transitional rules in Law no. 17 of 2003, that the provisions on the state losses are binding on SOEs; and (v) the expansion of the phrase state losses in Law no. 20 of 2001 so that they can ensnare SOE directors and related parties.

\section{REFERENCES}

[1] R. Danendra, I. G. Ayu, K. Rachmi, and A. K. Jaelani, "Legal Protection of Non Wage Workers Rights After Omnibus Law," Jurisprudentie, vol. 8, no. 13, pp. 85-99, 2021.

[2] A. K. Jaelani and R. D. Luthviati, "The Crime Of Damage After the Constitutional Court's Decision Number 76 / PUU-XV / 2017," J. Hum. Rights, Cult. Leg. Syst., vol. 1, no. 1, pp. 31-41, 2021.

[3] R. D. Luthviati, "The Role of Local Governments in the Defense of Leading Products Resti," Bestuur, vol. 8, no. 2, pp. 121-128, 2020.

[4] F. U. Najicha, "Oil and Natural Gas Management Policy in Realizing Equal Energy in Indonesia," $J$. Hum. Rights, Cult. Leg. Syst., vol. 1, no. 2, pp. 7179, 2021.

[5] I. Iswantoro, "Strategy and Management of Dispute Resolution, Land Conflicts at the Land Office of Sleman Regency," J. Hum. Rights, Cult. Leg. Syst., vol. 1, no. 1, pp. 1-17, 2021.

[6] S. D. Baranyanan, "Simplification of Law Regulations in Copyright Criminal Act Settlement," J. Hum. Rights, Cult. Leg. Syst., vol. 1, no. 2, pp. 80-91, 2021.

[7] L. C. Lintang, Adriano Martufi, and J.W. Ouwerker, "The Alternative Concepts of Blasphemy Law in 
Indonesia: Legal Comparison with Ireland and Canada," Bestuur, vol. 8, no. 2, pp. 121-128, 2020.

[8] M. Pungky and H. Wijaya, "Legislation Impediments in Reorganising Government Bodies in Indonesia," Bestuur, vol. 9, no. 1, pp. 1-16, 2021.

[9] Saidah Fasihah Binti Che Yussoff and R. Nordin, "Freedom of Expression in Malaysia: Compatibility with the International Human Rights Standard Saidah," Bestuur, vol. 9, no. 1, pp. 44-59, 2021.

[10] U. K. Mishra and A. Negi, "Transgender and the Right to Employment in India: Analysing the Trajectories of Discrimination," Bestuur, vol. 9, no. 1, pp. 34-43, 2021

[11] S. R. Novikasari, D. Q. Ly, and K. Gershaneck, "Taxing Micro, Small and Medium Enterprises in Yogyakarta: Regulation and Compliance," Bestuur, vol. 9, no. 1, 2021.

[12] H. J. Noor, K. Afkar, H. Glaser, and U. G. Mada, "Application of Sanctions Against State Administrative Officials Failing to Implement Administrative Court Decisions," Bestuur, vol. 9, no. 1, pp. 73-93, 2021.

[13] N. P. Hidayah, "The Implementation of Labor Development Principles According to Job Creation Law as a Reason to Protect Wages Rights," Bestuur, vol. 8, no. 2, pp. 121-128, 2020.

[14] W. B. Putri et al., "Medicolegal Perspective on Physician-Induced Demand Issue," Bestuur, vol. 9, no. 1, pp. 106-124, 2021.

[15] I. G. A. K. R. Handayani, L. Karjoko, and A. K. Jaelani, "Model Pelaksanaan Putusan Mahkamah Konstitusi yang Eksekutabilitas Dalam Pengujian Peraturan Perundang-Undangan di Indonesia," Bestuur, vol. 7, no. 1, pp. 36-46, 2019.

[16] N. Ishak, R. R. Hasibuan, and T. S. Arbani, "Bureaucratic and Political Collaboration Towards a Good Governance System," Bestuur, vol. 8, no. 1, p. 19, 2020.

[17] Prasetio et al., "Problems of democratic and dignified election in indonesian simultaneously electoral era," Int. J. Criminol. Sociol., vol. 9, pp. 1701-1708, 2020.

[18] N. Zubaidi, R. G. Pratama, and S. Al-Fatih, "Legal Perspective on Effectiveness of Pre-Work Cards for Indonesian People," Bestuur, vol. 8, no. 1, p. 9, 2020.

[19] M. Roestamy, "Model Land Supply for Land Bank to House Application Martin," Bestuur, vol. 7, no. 2, 2019.

[20] D. E. Wibowo, "Ewuh Pakewuh Cultural Reconstruction to Equal Consumer Protection," $J$. Best., vol. 8, no. 1, pp. 1-8, 2020.

[21] A. D. Nuryanto, "Problem Penyidikan Tindak Pidana Pencucian Uang yang Berasal dari Predicate Crime Perbankan," Bestuur, vol. 7, no. 1, p. 54, 2019.

[22] T. Triwanto and E. Aryani, "The Urgency of Granting Authority to Assess Corruption Justice Collaborators," Bestuur, vol. 8, no. 1, p. 60, 2020.

[23] Z. N. Rosidah, "Coherence of the Rules of Sharia
Against Pancasila," Bestuur, vol. 8, no. 1, p. 40, 2020.

[24] L. Kajoko, Z. N. Rosidah, and I. G. A. K. R. Handayani, "Refleksi Paradigma Ilmu Pengetahuan Bagi Pembangunan Hukum Pengadaan Tanah," Bestuur, vol. 7, no. 1, pp. 1-14, 2019.

[25] L. Karjoko et al., "PATENT POLICY ON THE PHARMACEUTICAL SECTOR IN INDONESIA," vol. 23, no. 5, pp. 1-13, 2020.

[26] L. Karjoko, I. G. A. K. R. Handayani, A. S. Sudarwanto, D. W. Winarno, A. K. Jaelani, and W. N. Hanum, "THE CONSEQUENCE OF THE DECISION OF THE CONSTITUTIONAL COURT IN FORESTRY ON THE RECOGNITION OF TRADITIONAL FORESTS IN," J. Leg. Ethical Regul. Issues, vol. 24, no. 5, pp. 1-8, 2021.

[27] A. L. S. Sudarwanto et al., "POSITION OF FREEDOM OF CONTRACT PRINCIPLE IN FORESTRY PARTNERSHIP POLICY," J. Leg. Ethical Regul. Issues, vol. 24, no. 5, pp. 1-11, 2021.

[28] A. K. Jaelani, I. G. A. K. R. Handayani, and L. Karjoko, "Development of tourism based on geographic indication towards to welfare state," Int. J. Adv. Sci. Technol., vol. 29, no. 3 Special Issue, pp. 1227-1234, 2020.

[29] Soediro, I. G. A. K. R. Handayani, and L. Karjoko, "The spatial planning to implement sustainable agricultural land," Int. J. Adv. Sci. Technol., vol. 29, no. 3 Special Issue, pp. 1307-1311, 2020.

[30] A. B. Kuncoro, G. A. K. R. Handayani, Y. T. Muryanto, and L. Karjoko, "Urgency of government protection on consumers in the concept of the rule of law," Int. J. Adv. Sci. Technol., vol. 28, no. 20, pp. 331-335, 2019.

[31] A. K. Jaelani, I. G. A. K. Rachmi Handayani, and L. Karjoko, "EXECUTABILITY OF THE CONSTITUTIONAL COURT DECISION REGARDING GRACE PERIOD IN THE FORMULATION OF LEGISLATION," Int. J. Adv. Sci. Technol., vol. 28, no. 15, pp. 816-823, 2019. 